\title{
Uji Daya Hambat Formula Gel Ekstrak Etanol Daun Murbei (Morus Alba L.) Sebagai Anti Acne Terhadap Bakteri Propionibacterium acne
}

\section{(Inhibition Test of Ethanol Extract Gel of Mulberry (Morus alba L.) Leaves as an Anti- Acne on Propionibacterium acne Bacteria)}

\author{
Ahmad Irsyad Aliah, Wahyuni, Nurjannah Bachri \\ Program Studi Farmasi, Fakultas FATERSI, Universitas Megarezky, Makassar, Indonesia, 90234
}

\author{
Article Info: \\ Received: 24 September 2019 \\ in revised form: 10 October 2019 \\ Accepted: 24 October 2019 \\ Available Online: 24 October 2019 \\ \begin{tabular}{l} 
Keywords: \\
Inhibition test \\
Extract \\
mulberry leaves \\
Gel \\
Propionibacterium acne. \\
\hline \\
Corresponding Author: \\
Ahmad Irsyad Aliah \\
Program Studi Farmasi \\
Fakultas FATERSI \\
Universitas Megarezky \\
Makassar, 90234 \\
Indonesia \\
email: ahmadirsyadaliah@gmail.com
\end{tabular}
}

\begin{abstract}
To facilitate the use of mulberry (Morus alba L.) leaf extract in the treatment of acne, then it was formulated into pharmaceutical dosage form, in the form of gel. The gel has several advantages including non-stickiness, high water content in the gel, so that the large amount of water in the gel will hydrate the stratum corneum and change the permeability of the stratum corneum to be more permeable on active substance which can increase the permeation of the active substance. This study aims to formulate a gel formulation made by using mulberry leaf extract (Morus alba L.), and then determine the antibacterial inhibition of gel of mulberry (Morus alba L.) leaf extract against the bacteria Propionibacterium acne. Gel was made by three dosage concentrations of $2 \%, 4 \%$ and $6 \%$. Inhibition test of antibacteria was done by agar diffusion method. Antibacterial inhibition was obtained by observing the clear zone in the medium and measured using calipers. The results showed the inhibition of antibacterial activity of gel formulation of concentration $2 \%, 4 \%$ and $6 \%$ with inhibitory zone of $15.7 \mathrm{~mm}, 20.3 \mathrm{~mm}$, and $21.7 \mathrm{~mm}$, respectively.
\end{abstract}




\begin{abstract}
ABSTRAK
Untuk memudahkan penggunaan dari ekstrak daun murbei (Morus alba L.) pada pengobatan jerawat, maka dari itu di formulasikan dalam bentuk sediaan farmasi yaitu dalam bentuk gel. Gel mempunyai beberapa keuntungan diantaranya yaitu tidak lengket, kadar air dalam gel tinggi, sehingga jumlah air yang banyak dalam gel akan menghidrasi stratum corneum dan terjadi perubahan permeabilitas stratum corneum menjadi lebih permeabel terhadap zat akif yang dapat meningkatkan permeasi zat aktif. Penelitian ini bertujuan untuk membuat sediaan gel dari ekstrak daun murbei (Morus alba L.) dan menentukan daya hambat antibakteri gel ekstrak daun murbei (Morus alba L.) tersebut terhadap bakteri Propionibacterium acne. Gel dibuat tiga kosentrasi sediaan yaitu 2\%, 4\%, dan 6\%. Pengujian daya hambat antibakteri gel menggunakan metode difusi agar. Uji daya hambat antibakteri diperoleh dengan melihat zona bening pada medium dan diukur dengan menggunakan jangka sorong. Hasil daya hambat antibakteri menunjukan bahwa sediaan gel dengan konsentrasi $2 \%, 4 \%$, dan $6 \%$ menunjukan aktivitas yang menghambat bakteri dengan diameter hambat masing-masing adalah $15,7 \mathrm{~mm} ; 20,3$ $\mathrm{mm}$; dan $21,7 \mathrm{~mm}$.
\end{abstract}

Kata kunci: Uji daya hambat, Ekstrak, daun murbei, Gel, Propionibacterium acne.

\section{PENDAHULUAN}

Salah satu penyakit kulit yang banyak dijumpai secara global pada remaja dan dewasa muda adalah jerawat atau Acne vulgaris (Adhi et al., 2008). Akne vulgaris adalah suatu kelainan dari folikel sebasea khusus yang berkaitan dengan folikel rambut dan kelenjar sebasea yang tersering dijumpai pada wajah, dada, dan punggung (Al-Hoqail, 2003). Meskipun akne vulgaris tidak menimbulkan fatalitas, tetapi akne dapat cukup merisaukan karena berhubungan dengan menurunnya kepercayaan diri akibat berkurangnya keindahan pada wajah penderita (American Family Physician, 2019).

Jerawat dapat diobati dengan suatu obat antibakteri. Salah satu tanaman yang terbukti memiliki daya antibakteri adalah daun murbei (Morus alba L.). Senyawa dalam daun murbei (Morus alba L.) umumnya berupa alkaloid, polifenol dan flavanoid yang berfungsi sebagai antibakteri dengan cara membentuk senyawa kompleks terhadap protein ekstraseluler yang mengganggu integrasi membran sel bakteri (Utami et al., 2012).

Untuk kemudahan penggunaan dari ekstrak daun murbei (Morus alba L.) pada pengobatan jerawat, maka dari itu di formulasikan dalam bentuk sediaan farmasi yaitu dalam bentuk gel. Gel mempunyai beberapa keuntungan diantaranya yaitu tidak lengket, kadar air dalam gel tinggi, sehingga jumlah air yang banyak dalam gel akan menghidrasi stratum corneum dan terjadi perubahan permeabilitas stratum corneum menjadi lebih permeabel terhadap zat akif yang dapat meningkatkan permeasi zat aktif (Anggraini et al., 2013).

Berdasarkan latar belakang diatas penelitian yang akan dilakukan berbeda dengan penelitian sebelumnya, karena penelitian ini melakukan uji daya hambat formula gel ekstrak etanol daun murbei (Morus alba L.) sebagai anti acne dengan variasi konsentrasi $2 \%, 4 \%$ dan $6 \%$ terhadap bakteri Propionibacterium acne.

Adapun rumusan masalah dari penelitian ini adalah untuk mengetahui apakah formula gel ekstrak etanol daun murbei (Morus alba L.) sebagai anti acne dengan variasi konsentrasi $2 \%, 4 \%$, dan $6 \%$ dapat menghambat bakteri Propionabacterium acne.

Dari rumusan masalah diatas maka dapat ditarik sebuah tujuan, yakni Untuk mengetahui uji daya hambat formula gel ekstrak etanol daun murbei (Morus alba L.) sebagai anti acne dengan variasi konsentrasi $2 \%$, 4\%, dan $6 \%$ terhadap bakteri Propionabacterium acne.

Dengan berorientasi pada tujuan penelitian maka dapat disimpulkan bahwa urgensi penelitian ini antara lain untuk memperoleh formulasi gel ekstrak daun Murbei (Morus alba L.) yang stabil baik secara fisik maupun kimia serta untuk mengetahui konsentrasi yang baik dari formula gel ekstrak daun 
Murbei (Morus alba L.) yang berefek sebagai anti acne.

\section{METODE PENELITIAN}

\begin{abstract}
Alat dan Bahan
Alat-alat yang digunakan adalah, cawan petri (pyrex), cawan porselin, gelas kimia (pyrex), gelas ukur (pyrex), inkubator, ose, jangka sorong, labu erlenmeyer(pyrex), lampu spiritus, labu ukur (pyrex), autoklaf, oven, penangas air, tabung reaksi, timbangan analitik, spoit $5 \mathrm{cc}$.
\end{abstract}

Bahan-bahan yang digunakan adalah etanol $70 \%$, air suling, Gel ekstrak etanol daun murbei, medium nutrient agar, natrium klorida, biakan murni Propionabacterium acne, paper disk (kertas cakram).

\section{Metode}

\section{Jenis Penelitian}

Metode penelitian dilakukan dengan menggunakan metode eksperimen skala laboratorium dengan metode difusi agar menggunakan paper disk (Djide \& Sartini, 2012).

\section{Waktu dan Tempat Penelitian}

Waktu penelitian dilakukan pada bulan Februari 2017. Penelitian akan dilaksanakan di Laboratorium Mikrobiologi Farmasi, Universitas Megarezky di Kota Makassar, Sulawesi Selatan.

\section{Alat dan Bahan yang digunakan}

Alat-alat yang akan digunakan adalah, cawan petri (pyrex), cawan porselin, gelas kimia (pyrex), gelas ukur (pyrex), inkubator, ose, jangka sorong, labu erlenmeyer(pyrex), lampu spiritus, labu ukur (pyrex), autoklaf, oven, penangas air, tabung reaksi, timbangan analitik, spoit $5 \mathrm{cc}$.

Bahan-bahan yang akan digunakan adalah etanol $70 \%$, air suling, Gel ekstrak etanol daun murbei, medium nutrient agar, natrium klorida, biakan murni Propionabacterium acne, paper disk (kertas cakram).

\section{Pengambilan dan penyiapan sampel}

\section{Pengambilan sampel}

Sampel daun murbei diambil di daerah bili-bili bonto marannu kab gowa, Sulawesi Selatan.

\section{Pengolahan sampel}

Sampel daun murbei (Morus alba L.) yang digunakan adalah daun kelima dari pucuk sampai pangkal yang tidak berwarna kekuningan dan rusak, dicuci bersih dengan air mengalir lalu ditiriskan, dipotong-potong kecil, kemudian dikeringkan dengan cara dianginanginkan pada tempat yang tidak terkena cahaya matahari langsung. Kemudian sampel ditimbang 1 $\mathrm{kg}$, Setelah itu sampel diekstraksi dengan metode maserasi menggunakan pelarut etanol $70 \%$.

\section{Pembuatan Bahan Penelitian}

\section{Pembuatan Ekstrak Daun Murbei}

Sebanyak $1 \mathrm{~kg}$ daun murbei dimasukkan ke dalam bejana maserasi yang ditambahkan etanol $70 \%$ sebanyak $2000 \mathrm{~mL}$, sampel diaduk. Setelah 3 hari cairan penyari diganti dengan etanol $70 \%$ yang baru sebanyak $2000 \mathrm{~mL}$, kemudian sampel diaduk.Penggantian cairan penyari dilakukan sebanyak 1 kali sehari dengan jumlah penyari yang sama yaitu $2000 \mathrm{~mL}$. Penggantian cairan dilakukan sebanyak 3 kali. Ekstrak etanol $70 \%$ yang diperoleh kemudian dikumpulkan dan diuapkan cairan penyarinya dengan menggunakan rotavapor dan dimasukkan kedalam eksikator hingga diperoleh ekstrak kental (Dirjen POM, 2000).

\section{Penyiapan Medium Nutrient Agar}

Medium NA (Nutrient Agar) dibuat dengan menimbang Nutrient agar sebanyak 2 gram lalu dilarutkan dengan air suling hingga $100 \mathrm{ml}$ pada labu Erlenmeyer dan dipanaskan hingga larut kemudian disterilkan di dalam autoklaf pada suhu $121^{\circ} \mathrm{C}$, tekanan 1 atm selama 15 menit. Untuk inokulasi bakteri sebanyak $3 \mathrm{~mL}$ medium yang telah dipanaskan (Fifendy, 2017).

\section{Penyiapan Bakteri Uji}

Bakteri uji yang digunakan adalah bakteri Propionabacterium acne yang diperoleh dari Laboratorium Mikrobiologi Farmasi Universitas Hasanuddin, Makassar.

\section{Peremajaan Kultur Murni Propionabacterium acne}

Kultur murni, Propionabacterium acne digores dan diinokulasi secara aseptis dengan cara digoreskan 
pada agar miring dari medium NA, lalu diinkubasi secara anaerob pada suhu $37^{\circ} \mathrm{C}$ selama 24 jam.

\section{Pembuatan Suspensi Murni Propionabacterium acne}

Bakteri uji hasil peremajaan disuspensikan dengan larutan fisiologis ( $\mathrm{NaCl}$ 0,9\%) sebanyak $3 \mathrm{ml}$ kedalam vial.

\section{Pembuatan Bakteri Uji}

Suspensi murni Propionabacterium acne digores dan dimasukkan kedalam vial yang berisi medium NA, digoyang atau dihomogenkan, kemudian dituang kedalam cawan petri yang telah berisi medium NA.

\section{Pengujian Daya Hambat}

Pengujian aktivitas antimikroba ekstrak etanol daun murbei pada sediaan gel sebagai anti acne terhadap pertumbuhan bakteri Propionabacterium acne dilakukan dengan metode difusi agar dengan menggunakan kertas cakram. Pada ketiga gel yang telah diformulasi dan kontrol negatif, dicelupkan kertas cakram, didiamkan selama kurang lebih 3 menit, kemudian diangkat dan dibiarkan sampai agak mengering selama kurang 3menit, kemudian diletakkan secara aseptis pada permukaan medium uji yang memadat (Fifendy, 2017).

\section{Pengamatan aktivitas Antimikroba}

Pengamatan dilakukan setelah masa inkubasi 24 jam dan 48 jam. Diameter hambatan diukur berdasarkan KHM (Waluyo, 2019).

\section{Pembuatan Basis Gel}

Basis dibuat dengan cara karbopol didispersikan dengan air suling sebanyak $50 \mathrm{ml}$, lalu dilarutkan metil paraben dengan air mendidih secara terpisah, kemudian dituang kedalam lumpang yang telah berisi karbopol, dihomogenkan dan dicukupkan volumenya dengan sisa air suling sebanyak $50 \mathrm{ml}$ (Ansel, 2008).

\section{Pembuatan gel}

Gel dibuat terlebih dahulu dengan membuat kontrol dengan cara didispersikan dengan air suling sebanyak $50 \mathrm{ml}$ yang sebelum metil paraben dicampur kedalam air tersebut, kemudian dengan ditambahkan propilen glikol, gliserin, dan trietanolamin, selanjutnya dihomogenkan hingga terbentuk gel.
Pembuatan gel ekstrak etanol daun murbei (Morus alba L.) dengan konsentrasi $2 \%$ dibuat dengan didespersikan karbopol dengan air suling sebanyak $50 \mathrm{ml}$, yang telah ditambahkan dengan metil paraben diaduk hingga homogen, Selanjutnya disimpan pada wadah. Selanjutnya pada wadah kedua didespersikan ekstrak etanol daun murbei (Morus alba L.) dalam propilenglikol, gliserin, trietanolamin, aduk hingga homogen masukan basis yang terdapat pada wadah pertama kedalam wadah kedua, selanjutnya homogenkan. Pembuatan gel ekstrak etanol daun murbei (Morus alba L.) dengan konsentrasi 4\%, 6\% dibuat dengan cara seperti konsentrasi $2 \%$ dimana dibuat dengan didispersikan karbopol dengan air suling sebanyak $50 \mathrm{ml}$, yang telah ditambahkan dengan methil paraben diaduk hingga homogen, ditambahkan dengan propilenglikol, gliserin, dan trietanolamin, selanjutnya dihomogenkan hingga terbentuk gel Selanjutnya disimpan pada wadah. Selanjutnya pada wadah kedua didispersikan ekstrak etanol daun murbei (Morus alba L.) dalam propilenglikol, gliserin, trietanolamin, aduk hingga homogen masukan basis yang terdapat pada wadah pertama kedalam wadah kedua, selanjutnya homogenkan. Formulasi gel dapat diamati pada tabel 1 dan gambar 1 .

\section{Pembuatan Kontrol Positif (gel jerawat paten)}

Gel jerawat paten $1 \mathrm{mg}$, dilarutkan dengan aquades sebanyak $10 \mathrm{ml}$ diaduk dengan menggunakan batang pengaduk hingga larut.

\section{Pengumpulan Data}

Data yang diperoleh dari hasil pengamatan dari masing-masing kelompok perlakuan.

\section{HASIL DAN PEMBAHASAN}

Uji daya hambat merupakan percobaan yang dilakukan untuk mengidentifikasi daerah hambat suatu zat anti mikrobial terhadap mikroorganisme. Antibakteri adalah zat-zat atau senyawa yang dapat membunuh atau menghambat pertumbuhan bakteri. Gel merupakan sediaan semipadat yang jernih, tembus cahaya dan mengandung zat aktif, merupakan dispersi koloid mempunyai kekuatan yang disebabkan oleh jaringan yang saling berikatan pada fase terdispersi. 
Tabel 1. Formulasi Gel Ekstrak Murbei

\begin{tabular}{|c|c|c|c|c|c|}
\hline \multirow{2}{*}{ Bahan } & \multirow{2}{*}{ Kegunaan } & \multicolumn{4}{|c|}{ Konsentrasi Bahan } \\
\hline & & F $0(\%)$ & F I (\%) & FII (\%) & FIII (\%) \\
\hline $\begin{array}{c}\text { Ekstrak daun } \\
\text { murbei }\end{array}$ & Zat aktif & 0 & 2 & 4 & 6 \\
\hline Karbopol & Basis gel & 0,5 & 0,5 & 0,5 & 0,5 \\
\hline Metil Paraben & Pengawet & 0,2 & 0,2 & 0,2 & 0,2 \\
\hline Propilen glikol & Kosolven & 10 & 10 & 10 & 10 \\
\hline Trietanolamin & $\begin{array}{c}\text { Penetralisir } \\
\text { dan pengembang }\end{array}$ & 1 & 1 & 1 & 1 \\
\hline Gliserin & Humektan & 10 & 10 & 10 & 10 \\
\hline Air suling & Pelarut ad & $100 \mathrm{ml}$ & 100ml & $100 \mathrm{ml}$ & $100 \mathrm{ml}$ \\
\hline
\end{tabular}

Keterangan :

F0 : Formula gel tanpa ekstrak, F1: Formula gel dengan ekstrak konsentrasi 2\%, FII : Formula gel dengan ekstrak konsentrasi 4\%, FIII: Formula gel dengan ekstrak konsentrasi 6\%

Tabel 2. Hasil pengukuran diameter zona hambat (mm) formula gel ekstrak daun murbei (Morus alba L) sebagai anti acne terhadap bakteri Propionibacterium acne

\begin{tabular}{cccc}
\hline Bakteri uji & Konsentrasi & $\begin{array}{c}\text { Daya } \\
\text { hambat }\end{array}$ & Kesimpulan \\
\hline $\begin{array}{c}\text { Propionibact } \\
\text { erium acne }\end{array}$ & Kontrol negatif & $0 \mathrm{~mm}$ & $\begin{array}{c}\text { Tidak } \\
\text { terbentuk }\end{array}$ \\
& Kontrol positif & 14 & Lemah \\
& & $\mathrm{mm}$ & \\
& $2 \%$ & 15,7 & Lemah \\
& $\mathrm{mm}$ & \\
& 20,3 & Kuat \\
& $\mathrm{mm}$ & \\
& 21,7 & Kuat \\
\end{tabular}

Keterangan : Lemah : 10-15 mm, Sedang : 16-20 mm, Kuat : >20 $\mathrm{mm}$ (Rohan, 2017).

Berdasarkan tabel 2, pada konsentrasi formula gel ekstrak etanol daun murbei (Morus alba L.) 2\%, 4\%, dan $6 \%$ memiliki adanya daya hambat, sehingga dapat dikatakan dapat menghambat pertumbuhan Propionibacterium acne.

Penyiapan sampel pada penelitian ini yaitu dimana daun murbei (Morus alba L.) diekstraksi dengan menggunakan metode maserasi dengan cara daun murbei yang telah kering dimasukan kedalam bejana lalu ditambahkan pelarut etanol $70 \%$ hingga melewati batas sampel lalu disimpan pada ruangan tertutup yang terhindar cahaya matahari sambil diaduk berulang kali. Ditambahkan etanol $70 \%$ karena etanol $70 \%$ sangat efektif dalam menarik kandungan zat aktif dalam daun murbei. Setelah 3 hari perendaman disaring hingga didapatkan maserat.

Kemudian ampas dimaserasi kembali menggunakan pelarut yang sama dan dengan prosedur yang sama juga. Proses maserasi dilakukan sampai 3 kali agar diperoleh maserat yang lebih banyak, semua maserat digabungkan menjadi satu kedalam wadah yang telah disiapkan kemudian diuapkan menggunakan kipas untuk mendapatkan ekstrak kental.

Selanjutnya ekstrak kental daun murbei diformulasikan dalam bentuk sediaan farmasi yaitu gel dengan menggunakan variasi konsentrasi yaitu $2 \%, 4 \%$, dan $6 \%$. Berdasarkan penelitian sebelumnya yang dilakukan Utami et al., (2012) membuktikan bahwa daun dan buah murbei (Morus alba L.) memiliki aktifitas antibakteri terhadap Staphylococcus aureus dan Shigella dysenteriae dengan konsentrasi ekstrak daun maupun buah murbei (Morus alba L.) yang paling efektif dalam menghambat pertumbuhan Staphylococcus aureus ialah $85 \%$. Digunakan konsentrasi 2\%, 4\%, dan 6\% karena untuk mengetahui daya hambat antibakteri daun murbei (Morus alba L.) pada konsentrasi rendah apakah dapat menghambat pertumbuhan bakteri Propionibacterium acne. dan untuk konsentrasi ekstrak daun murbei (Morus alba L.) Dibuat pembuatan kontrol negatif dengan menggunakan sediaan gel tanpa ekstrak daun murbei. Sedangkan pembuatan kontrol positif menggunakan sediaan gel jerawat paten. 
Dalam penelitian ini dilakukan uji daya hambat formula gel ekstrak etanol daun murbei (Morus alba L.) sebagai anti acne terhadap bakteri Propionibacterium acne dimana medium NA dituangkan kedalam cawan petri yang merupakan media pertumbuhan mikroba uji. Pembuatannya dengan cara ditimbang 2 gram lalu dilarutkan kedalam $100 \mathrm{ml}$ aquades kemudian didihkan pada penangas air hingga bening dan ditutup dengan aluminium foil, dibiarkan hingga memadat. Kemudian dilakukan inokulasi pada media miring yaitu bakteri Propionibacterium acne diambil dengan jarum ose steril kemudian digoreskan pada medium miring secara zig-zag lalu diinkubasi selama 24 jam. Setelah itu dilakukan suspensi bakteri dengan menggunakan larutan fisiologi $\mathrm{NaCl} 0,9 \%$, setelah itu dilakukan pengujian antibakteri dengan cara media NA yang telah dicampur suspensi bakteri dituang secara aseptis kedalam cawan petri lalu disimpan ditempat yang datar sambil dibiarkan memadat.

Pada penelitian ini menggunakan 4 cawan petri dimana cawan petri dibagi masing-masing 2 cawan petri diletakan 3 paper disk yang telah dicelupkan kedalam formula gel ekstrak daun murbei (Morus alba L.) dengan konsentrasi yang berbeda (2\%, $4 \%$, dan $6 \%$ ) perlakuan yang sama untuk kontrol positif dan negatif. Kemudian cawan petri dibungkus menggunakan kertas lalu diinkubasi dalam inkubator dengan suhu $37^{\circ} \mathrm{C}$ selama 1 x 24 jam.

Hasil pengamatan uji daya hambat antibakteri sediaan gel ekstrak etanol daun murbei (Morus alba L.) menunjukan hasil bahwa gel yang hanya mengandung basis tidak memiliki zona hambat (kontrol negatif), sedangkan gel yang mengandung ekstrak memberikan zona hambat terhadap Propionibacterium acne dan pada sediaan paten gel jerawat juga memiliki zona hambat terhadap bakteri Propionibacterium acne (kontrol positif).

Hal ini berdasarkan hasil pengukuran rata-rata diameter hambatan disekitar paper disk gel ekstrak etanol daun murbei (Morus alba L.) pada masa inkubasi 24 jam. Formulasi dengan kosentrasi 6\% dengan diameter zona hambat $21,7 \mathrm{~mm}$ menunjukan zona hambat kuat dengan range yaitu $>20 \mathrm{~mm}$ ,selanjutnya formulasi dengan kosentrasi $4 \%$ dengan diameter zona hambat $20,3 \mathrm{~mm}$ menunjukan zona hambat sedang dengan range yaitu $16-20 \mathrm{~mm}$ dan formulasi dengan kosentrasi $2 \%$ dengan zona hambat lemah 15,7 mm menunjukan zona hambat lemah dengan range yaitu 10-15 mm (Gambar 2).
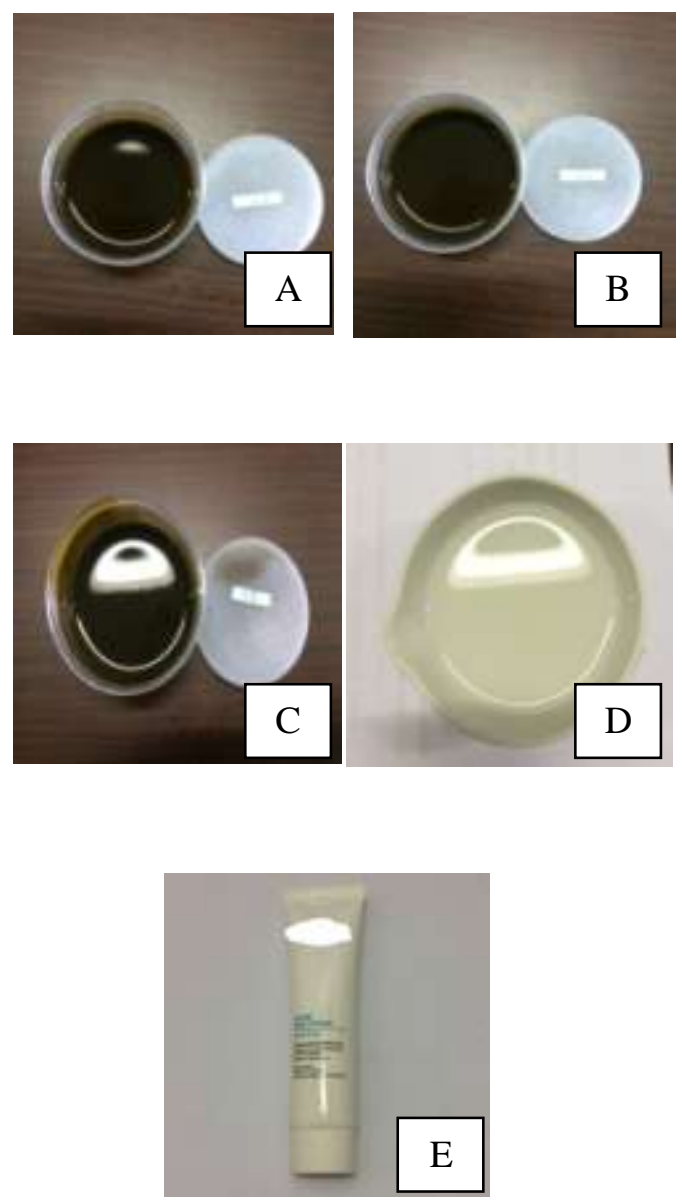

Gambar 1. Formulasi Gel Esktrak Etanol daun Murbei $2 \%$ (A), $4 \%$ (B), $6 \%$ (C), Kontrol Negatif Basis Gel (D), dan Kontrol positif gel anti acne (E)

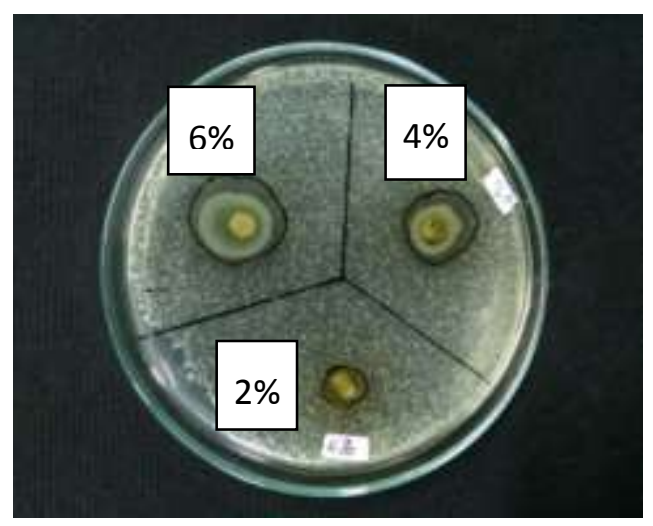

Gambar 2. Zona Hambat Formulasi Gel 2\%, 4\%, dan 6\% 
Sedangkan untuk kontrol positif dengan diameter zona hambat $14 \mathrm{~mm}$ menunjukan zona hambat lemah dengan range yaitu 10-15 mm (Gambar 3).

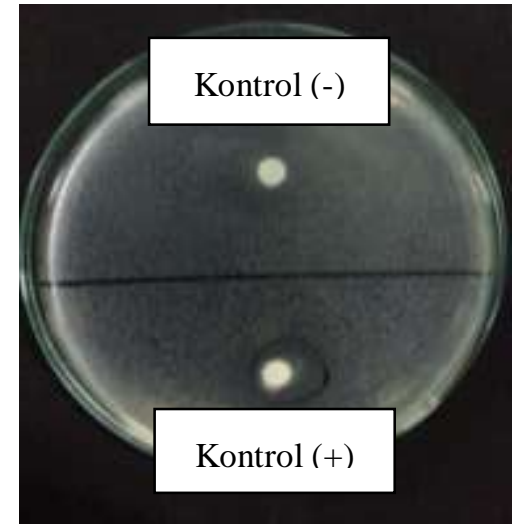

Gambar 3. Zona Hambat Kontrol Positif dan Negatif

Hal ini menunjukan bahwa senyawa aktif ekstrak daun murbei (Morus alba L.) efektif dalam menghambat pertumbuhan bakteri Propionibacterium acnes. Diketahui daun murbei memiliki kandungan senyawa yang bersifat sebagai antibakteri yaitu flavanoid, alkaloid, dan saponin (Musawwir, 2014). Hal ini yang menyebabkan bakteri Propionibakterium acne rentan terhadap bahan antimikrobial yaitu ekstrak daun murbei yang mengandung senyawa sebagai antibakteri (Miratunnisa et al., 2015).

\section{KESIMPULAN}

Berdasarkan hasil penelitian yang telah dilakukan maka dapat disimpulkan bahwa sediaan gel anti acne ekstrak etanol daun murbei (Morus alba L.) sangat efektif dalam menghambat pertumbuhan bakteri Propionibacterium acne. Hasil daya hambat antibakteri menunjukan bahwa sediaan gel dengan konsentrasi $2 \%, 4 \%$, dan $6 \%$ menunjukan aktivitas yang menghambat bakteri dengan diameter hambat masing-masing adalah $15,7 \mathrm{~mm} ; 20,3 \mathrm{~mm}$; dan 21,7 $\mathrm{mm}$.

\section{UCAPAN TERIMAKASIH}

Ucapan terima kasih penulis ucapkan kepada pihakpihak terkait yang membantu dalam penyelesaian penelitian ini, khususnya kepada Kementrian Riset, Teknologi dan Pendidikan Tinggi yang membiayai keseluruhan pelaksanaan penelitian ini dan kepada pihak-pihak Universitas Megarezky pada umumnya dan terkhusus kepada program studi S1 Farmasi Universitas Megarezky.

\section{DAFTAR PUSTAKA}

Adhi, D., Hamzah, M., \& Aisyah, S. (2008). Akne vulgaris. Dalam: Ilmu Penyakit Kulit dan Kelamin. (Edisi ke-5). Jakarta: Fakultas Kedokteran Universitas Indonesia.

Al-Hoqail, I. A. (2003). Knowledge, beliefs and perception of youth toward acne vulgaris. Saudi Med Journal, 24(7), 765-768.

American Family Physician, (2019). Acne. USA: American Family Physician. Retrieve from http://www.aafp.org/afp/20040501/2135ph.ht $\mathrm{ml} /$

Anggraini, D., Rahmawati, N., \& Hafsah, S. (2013). Formulasi Gel Antijerawat dari Ekstrak Etil Asetat Gambir. Jurnal Penelitian Farmasi Indonesia, 1(2), 62-66.

Ansel, H.C., (2008) Pengantar Bentuk Sediaan Farmasi Edisi IV. Depok: UI Press.

Direktorat Jenderal POM. (2000). Parameter Standar Umum Ekstrak Tumbuhan Obat. Jakarta: Departemen Kesehatan Republik Indonesia.

Djide, N. M., Sartini. (2012). Dasar-dasar Mikrobiologi Farmasi. Makassar: Lembaga Penerbit Universitas Hasanuddin Makassar (Lephas).

Fifendy, M. (2017). Mikrobiologi. Depok: Kencana.

Miratunnisa, Mulqie, L., Hajar, S. (2015). Uji Aktivitas Antibakteri Ekstrak Etanol Kulit Kentang (Solanum luberosum L) Terhadap Propionibacterium. Prosiding penelitian SPeSIA Unisba (pp. 510-516). Bandung: Indonesia. Prodi Farmasi fakultas MIPA Universitas Islam Bandung.

Musawwir. (2014). Daya Hambat Antibakteri Daun Murbei (Morus alba L) dan Penggunaannya Sebagai Konsentrat Terhadap Performa Ayam Buras Sel Telur. Skripsi Fakultas Peternakan Universitas Hasanuddin Makassar. Indonesia.

Rohan, H. H., Hartini, N., Sriwahyuni, E., Rokhmad, K., Ambarini, T. K. (2017). Mikrobiologi Dasar. Yogyakarta: Deepublish. 
Utami, H. S., Oktantia, A., \& Khasanah, H. N., (2012). Daya Antibakteri Ekstrak Etanol Daum Murbei (Morus alba L) Terhadap Staphylococcus aureus dan Shigella dysenteria. Prosiding pada Seminar Nasional IX Pendidikan Biologi FKIP UNS Malang (pp. 529-534). Malang, Indonesia: Biologi FMIPA Universitas Negeri Malang.

Waluyo, L. (2019) Mikrobiologi Umum. Malang: UMM Press. 